\title{
REDUCING WASTE DENGAN MENGGUNAKAN PENDEKATAN LEAN MANUFACTURING
}

\author{
Akhmad Jakfar, Wahyu Eko Setiawan, Ilyas Masudin \\ Jurusan Magister Manajemen, Universitas Muhammadiyah Malang \\ akhmad.jakfar89@gmail.com
}

\begin{abstract}
PT. XYZ is one of some cigarette companies in Indonesia. In producing cigarette, the firm requires a material named "etiket" which is produced by printing division for internal consumers of PT. XYZ. merupakan salah satu dari beberapa produsen rokok di Indonesia yang telah dikenal masyarakat. In order to produce "etiket", there are some wastes occurred. One of wastes occurred in printing division is product defects. This paper attempts to identify wastes in the division of printing using Lean Manufacturing approach by applying Value Stream Mapping (VSM) method.

The results from Cause Root analysis found that the problems caused the defects in production process. It shows that the most wastes occurs in the printing division are product defect and waiting time. The product defects are caused because there is no standard applied in processing the product and poor inspections by management, while the causes of waiting time wastes is because of lack of carrier and no standard in each process. The recommendation can be suggested to the company are adding some carrier (product's transporter), creating process standard in each process.
\end{abstract}

Keywords : Lean Manufacturing, Value Stream Mapping, Value Stream Analysis.

\section{PENDAhUluAN}

Setiap perusahaan manufaktur mengelola suatu proses produksi dalam rangka pemenuhan keinginan pelanggan. Proses produksi merupakan suatu tahapan untuk mengubah input menjadi output yang diinginkan. Proses produksi ini melibatkan seluruh sumber daya yang dimiliki oleh suatu perusahaan. Semakin meningkatnya persaingan bisnis dan tingginya tuntutan dari konsumen menuntut perusahaan untuk dapat mengelola proses produksi lebih efisien dan efektif (Pujawan, 2003). Untuk dapat mengelola proses produksi menjadi efektif dan efisien, banyak sekali metode yang digunakan, salah satunya adalah konsep lean manufacturing. Lean manufacturing merupakan metode untuk meningkatkan responsiveness melalui usaha pengurangan pemborosan (waste), continuous improvement dan cost reduction (Motwani, 2003).

PT. XYZ merupakan salah satu dari beberapa produsen rokok di Indonesia yang telah dikenal masyarakat. Beberapa merek telah dipasarkan dengan membidik segmen perokok dewasa dari beberapa golongan masyarakat, baik di pasar domestik maupun internasional. Semakin tingginya tingkat persaingan dalam industri rokok membuat PT. XYZ senantiasa berupaya meningkatkan pangsa pasarnya. Dalam ilmu pemasaran, kemasan atau packaging merupakan salah satu unsur penting karena dapat dapat dikatakan sebagai salah satu aspek yang mewakili citra perusahaan untuk bersaing dengan perusahaan lain untuk mendapatkan konsumen. Sebagai salah satu produsen rokok terbesar di Indonesia, PT. XYZ senantiasa memperhatikan mengenai kemasan atau packaging (etiket) dari produkproduknya. Oleh karena itu, PT. XYZ berusaha meningkatkan efisiensi proses produksi kemasan atau packaging dari produk-produknya.

Divisi printing adalah suatu divisi pada PT. XYZ yang memproduksi etiket kepada konsumen internal PT. XYZ. Salah satu produk yang dihasilkan oleh divisi printing adalah etiket "H" yang diproduksi untuk produk sigaret kretek tangan (SKT). Dalam proses produksi etiket " $\mathrm{H}$ ", masih sering terjadi waste yang disebabkan oleh beberapa hal. Salah satu jenis waste yang terjadi adalah produk defect. Gambar 1 menunjukkan defect ratio produk etiket "H" (berdasarkan data bulan oktober 2009 hingga Maret 2010). 


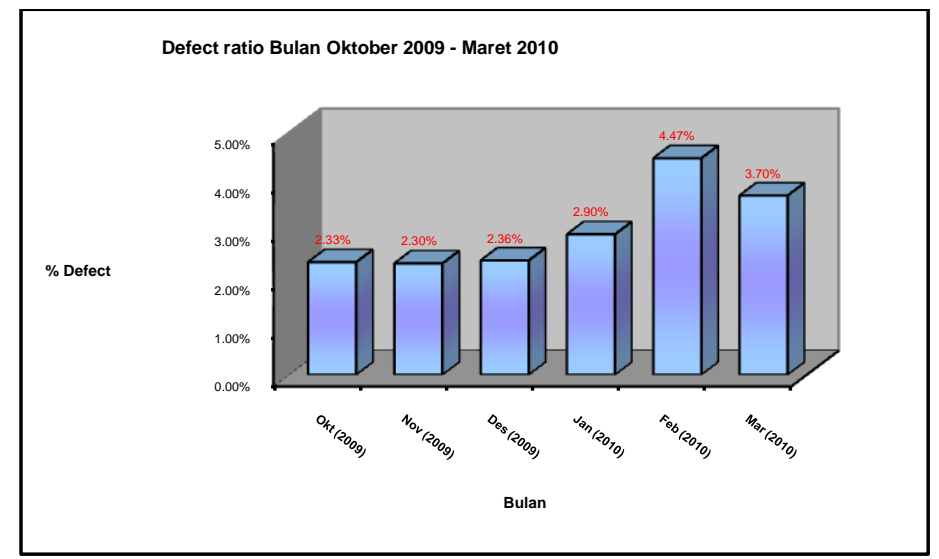

Gambar 1: Defect ratio produk etiket"H” bulan Oktober 2009 - Maret 2010.

Dalam rangka mengurangi waste yang terjadi dalam proses produksi, divisi printing ingin mengidentifikasi aktivitas-aktivitas internal produksi yang non-value-added dan necessary but non value added kemudian membuat suatu rancangan perbaikan yang efektif untuk mereduksi atau bahkan mengeliminasi waste tersebut sehingga perusahaan bisa menekan biaya produksi, mempersingkat lead time produksi dan meningkatkan profit margin perusahaan.

Berdasarkan permasalahan di atas maka peneliti mencoba untuk membuat perbaikan di lantai produksi dengan mengidentifikasi waste pada divisi printing PT. XYZ untuk produk etiket " $\mathrm{H}$ " dan mengetahui hubungan antara waste tersebut, selanjutnya menemukan akar permasalahan dari waste yang ada di lantai produksi dengan menggunakan pendekatan lean manufacturing. Salah satu tools yang dapat digunakan dalam lean manufacturing adalah value stream mapping (VSM). Aliran informasi dan material dari perusahaan dapat digambarkan dengan menggunakan value stream mapping. Menurut Vian and Landeghem, Value stream mapping (VSM) digunakan sebagai alat untuk untuk memudahkan proses implementasi lean dengan cara membantu mengidentifikasi tahapan-tahapan value-added di suatu aliran proses (value stream), dan mengeliminasi tahapan-tahapan non-value added atau waste (Irawan, 2007: 2). Hal tersebut akan dijadikan dasar dalam upaya rencana perbaikan sehingga dengan gambaran tersebut dapat diketahui proses produksi secara komprehensif.

Menurut Gaspersz (2007: 9) lean manufacturing merupakan suatu sistem produksi yang menggunakan energi dan pemborosan yang sangat sedikit untuk memenuhi apa yang menjadi keinginan konsumen dengan tepat. Tujuan dari lean manufacturing adalah mengeliminasi pemborosan (non value adding activity) dari suatu proses sehingga aktivitasaktivitas sepanjang value stream mampu menghasilakan value adding.

Menurut Suhartono (2007: 13-14), di dalam Toyota Production System (TPS) terdapat tujuh waste dalam proses produksi yaitu sebagai berikut:

Overproduction, Pemborosan yang disebabkan produksi yang berlebihan, maksudnya adalah memproduksi produk yang melebihi yang dibutuhkan atau memproduksi lebih awal dari jadwal yang sudah buat.

Waiting, Pemborosan karena menunggu untuk proses berikutnya. Waiting merupakan selang waktu ketika operator tidak menggunakan waktu untuk melakukan value adding activity dikarenakan menunggu aliran produk dari proses sebelumnya (upstream).

Transportation, transportasi merupakan kegiatan yang penting akan tetapi tidak menambah nilai pada suatu produk. Transportasi merupakan proses memindahkan material atau Work In Process (WIP) dari satu stasiun kerja ke stasiun kerja yang lainnya, baik menggunakan forklift maupun conveyor.

Excess Processing, terjadi ketika metode kerja atau urutan kerja (proses) yang digunakan dirasa kurang baik dan fleksibel. Hal ini juga dapat terjadi ketika proses yang ada 
belum standar sehingga kemungkinan produk yang rusak akan tinggi. Adanya variasi metode yang dikerjakan operator.

Inventories, Berarti persediaan yang kurang perlu. Maksudnya adalah Persediaan material yang terlalu banyak, Work In Process yang terlalu banyak antara proses satu dengan yang lainnya sehingga membutuhkan ruang yang banyak untuk menyimpannya, kemungkinan pemborosan ini adalah buffer yang sangat tinggi.

Motion, Berarti adalah aktivitas/pergerakan yang kurang perlu yang dilakukan operator yang tidak menambah nilai dan memperlambat proses sehingga lead time menjadi lama.

Defects, Berarti adalah produk yang rusak atau tidak sesuai dengan spesifikasi, hal ini akan menyebabkan proses rework yang kurang efektif, tingginya komplain dari konsumen, serta inspeksi level yang sangat tinggi.

\section{METODE PENELITIAN}

Penelitian ini termasuk jenis penelitian deskriptif, yaitu penelitian untuk mengadakan perbaikan terhadap suatu keadaan terdahulu. Penelitian ini dilaksanakan pada bulan Januari sampai dengan Maret 2010 di divisi printing pada PT. XYZ.

Langkah awal penelitian yang dilakukan adalah melakukan survei awal (survei pendahuluan) pada divisi printing PT. XYZ untuk mengumpulkan informasi yang berhubungan dengan proses produksi etiket " $\mathrm{H}$ ". Aktivitas yang dilakukan dalam tahap awal ini adalah mengamati situasi dan kondisi yang terjadi di perusahaan saat ini serta melakukan wawancara dengan pihak perusahaan mengenai permasalahan-permasalahan yang dihadapi oleh perusahaan. Value stream mapping diperlukan sebagai tahap awal sebelum melakukan analisis terjadinya waste dalam proses produksi untuk memberikan pemahaman mengenai proses produksi secara keseluruhan beserta aliran nilai (aliran informasi dan fisik) yang terdapat didalamnya.

Tahap identifikasi waste diperlukan untuk mengetahui waste apa saja yang terjadi dari proses produksi etiket "H" sebagai dasar untuk membuat rancangan perbaikan. Selanjutnya tahap analisis penyebab waste Tahap ini menjelaskan secara lebih detail dan terperinci mengenai waste yang terjadi dan penyebabnya.

\section{HASIL DAN PEMBAHASAN}

Proses pembuatan produk etiket " $\mathrm{H}$ " secara umum sepanjang value stream dimulai dari kedatangan bahan baku (kertas dan tinta) dari warehouse bahan baku, proses produksi, inspeksi produk, dan pengangkutan ke warehouse produk jadi. Berikut ini adalah detail aktivitas tiap proses produksi:

Tabel 1 Aktivitas dalam Proses Produksi etiket "H"

\begin{tabular}{cll}
\hline Kode & \multicolumn{1}{c}{ Aktivitas } & Keterangan \\
\hline A1 & Mengangkut bahan baku ke area produksi & Transportasi \\
\hline A2 & Mengangkut material dari area produksi ke mesin potong blangko & Transportasi \\
\hline A3 & Proses potong blangko & Operasi \\
\hline A4 & Mengangkut material dari mesin potong blangko ke WIP cetak & Transportasi \\
\hline A5 & Mengangkut material dari WIP cetak ke mesin cetak & Transportasi \\
\hline A6 & Proses cetak & Operasi \\
\hline A7 & Mengangkut material dari mesin cetak ke WIP Rit & Transportasi \\
\hline A8 & Mengangkut material dari WIP Rit ke mesin Rit & Transportasi \\
\hline A9 & Proses Rit & Operasi \\
\hline A10 & Mengangkut material dari mesin Rit ke WIP potong keping & Transportasi \\
\hline A11 & Mengangkut material dari WIP potong keping ke mesin potong & Transportasi \\
\hline A12 & Proses potong keeping & Operasi \\
\hline A13 & Mengangkut material dari mesin potong keping ke WIP sortir & Transportasi \\
\hline
\end{tabular}




\begin{tabular}{lll}
\hline A14 & Mengangkut material dari WIP sortir ke area sortir & Transportasi \\
\hline A15 & Proses sortir & Inspeksi \\
\hline A16 & Mengangkut material dari area sortir ke WIP QC sampling & Transportasi \\
\hline A17 & Inspeksi Printing QA & Inspeksi \\
\hline A18 & Mengangkut material dari WIP QC sampling ke area packing & Transportasi \\
\hline A19 & Proses packing & Operasi \\
\hline A20 & Mengangkut material dari area packing ke area wrapping & Transportasi \\
\hline A21 & Proses wrapping & Operasi \\
\hline A22 & Mengangkut dari area wrapping ke staging area & Transportasi \\
\hline A23 & Mengangkut dari staging area ke luar gedung (jalan) & Transportasi \\
\hline A24 & Mengangkut dari jalan ke warehouse produk jadi & Transportasi \\
\hline
\end{tabular}

Setiap aktivitas dalam proses produksi etiket "H" dapat berupa aktivitas yang bernilai tambah (VA), aktivitas yang tidak bernilai tambah (NVA) dan aktivitas yang perlu tetapi tidak bernilai tambah (NNVA). Penjabaran aktivitas dalam proses produksi dapat dilihat pada Tabel 2 berikut:

Tabel 2 Identifikasi Aktivitas dalam Proses Produksi Etket "H"

\begin{tabular}{|c|c|c|c|c|}
\hline \multirow{2}{*}{ No } & \multirow{2}{*}{ Aktivitas } & \multicolumn{3}{|c|}{ Kategori aktivitas *) } \\
\hline & & VA & NNVA & NVA \\
\hline A1 & Mengangkut bahan baku ke area produksi & & $\mathrm{V}$ & \\
\hline A2 & Mengangkut material dari area produksi ke mesin potong & & & $\mathrm{V}$ \\
\hline A3 & Proses potong blangko & $\mathrm{V}$ & & \\
\hline A5 & Mengangkut material dari WIP cetak ke mesin cetak & & $\mathrm{V}$ & \\
\hline A6 & Proses cetak & $\mathrm{V}$ & & \\
\hline A7 & Mengangkut material dari mesin cetak ke WIP Rit & & & $\mathrm{V}$ \\
\hline A8 & Mengangkut material dari WIP Rit ke mesin Rit & & $\mathrm{V}$ & \\
\hline A9 & Proses Rit & $\mathrm{V}$ & & \\
\hline $\mathrm{A} 12$ & Proses potong keeping & $\mathrm{V}$ & & \\
\hline A13 & $\begin{array}{l}\text { Mengangkut material dari mesin potong keping ke WIP } \\
\text { sortir }\end{array}$ & & & $\mathrm{V}$ \\
\hline A14 & Mengangkut material dari WIP sortir ke area sortir & & $\mathrm{V}$ & \\
\hline A15 & Proses sortir & & & $\mathrm{V}$ \\
\hline A16 & $\begin{array}{l}\text { Mengangkut material dari area sortir ke WIP QC } \\
\text { sampling }\end{array}$ & & & $\mathrm{V}$ \\
\hline A17 & Inspeksi Printing QA & & $\mathrm{V}$ & \\
\hline A18 & $\begin{array}{l}\text { Mengangkut material dari WIP QC sampling ke area } \\
\text { packing }\end{array}$ & & & $\mathrm{V}$ \\
\hline A19 & Proses packing & $\mathrm{V}$ & & \\
\hline A20 & Mengangkut material dari area packing ke area wrapping & & $\mathrm{V}$ & \\
\hline A21 & Proses wrapping & $\mathrm{V}$ & & \\
\hline A22 & Mengangkut dari area wrapping ke staging area & & & $\mathrm{V}$ \\
\hline $\mathrm{A} 23$ & Mengangkut dari staging area ke luar gedung (jalan) & & $\mathrm{V}$ & \\
\hline A24 & Mengangkut dari jalan ke warehouse finish product & & & $\mathrm{V}$ \\
\hline & Total aktivitas & 6 & 8 & 10 \\
\hline & Prosentase Aktivitas & $25.00 \%$ & $33.33 \%$ & $41.67 \%$ \\
\hline
\end{tabular}

\footnotetext{
${ }^{*}$ Keterangan:

$V A=$ Value added

$N N V A=$ Necessary but non- value added

NVA = Non-value added
} 


\section{A. Penyebab overproduction waste}

Sepuluh bulan terakhir terjadi overproduction karena hasil produksi melebihi target produksi. Berdasarkan hasil brainstorming dan pengamatan. Rencana produksi yang dibuat oleh pihak produksi tidak mengacu pada target produksi untuk setiap bulannya (schedule production monthly) yang telah ditetapkan oleh pihak PPC. Operator produksi mengejar target uptime yang tinggi, yaitu rasio antara output produksi dengan waktu produksi yang tersedia.

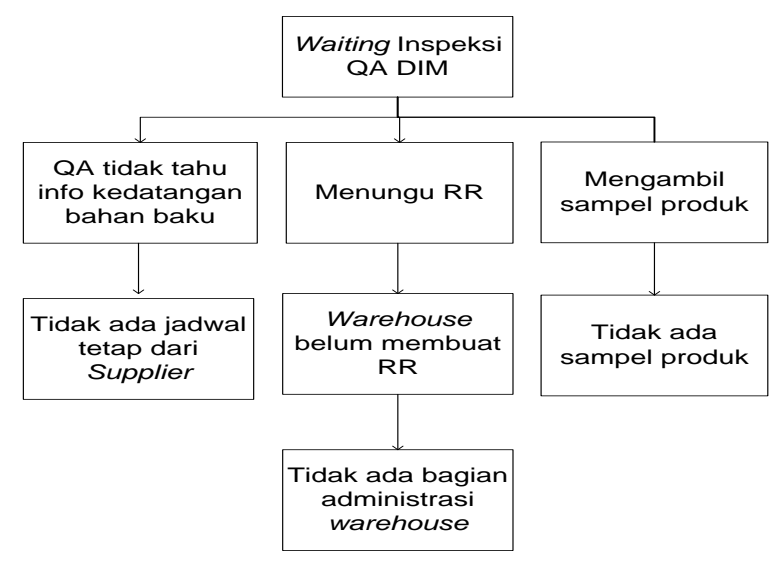

Gambar : RCA waiting inspeksi QA DIM.

\section{B. Penyebab waiting waste}

Pembongkaran bahan baku di warehouse bahan baku, pengangkutan bahan baku ke area produksi, proses inspeksi produk jadi and pengangkutan produk jadi ke truk.

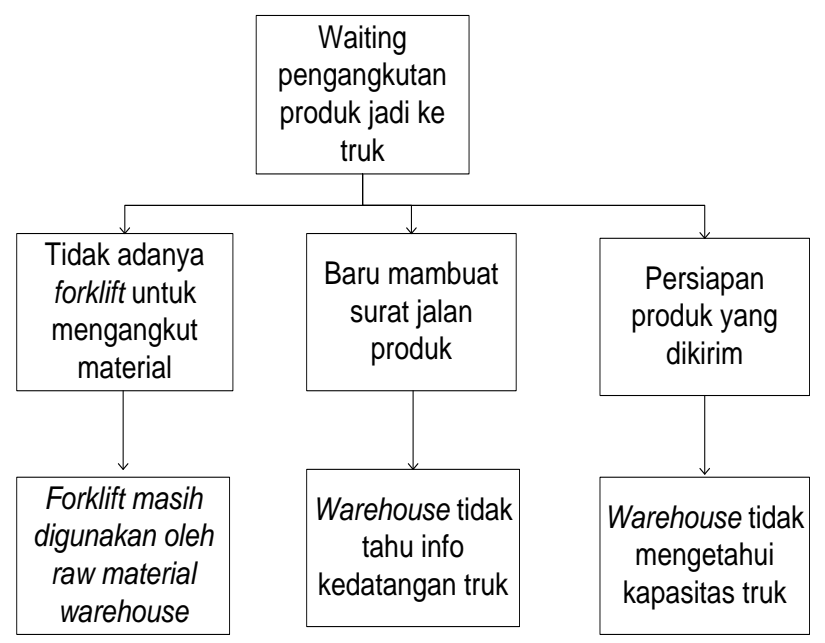

Gambar 3 RCA waiting pengangkutan produk jadi ke truk.

\section{Penyebab transportation waste}

Proses pengangkutan produk jadi dari area ke warehouse produk jadi dengan menggunakan diesel forklift kemudian dari warehouse produk jadi, produk diangkut menuju long term storage (LTS). Pada area produksi, masalah transportasi terjadi pada proses pemindahan material dari satu proses ke proses yang lain. 
Tabel 3 Jarak perpindahan material

\begin{tabular}{ll}
\hline \multicolumn{1}{c}{ Aktivitas } & Jarak (m) \\
\hline Mengangkut material dari area produksi ke mesin potong blangko & 14 \\
\hline Mengangkut material dari mesin potong blangko ke WIP cetak & 4 \\
\hline Mengangkut material dari WIP cetak ke mesin cetak & 13.5 \\
\hline Mengangkut material dari mesin cetak ke WIP Rit & 9 \\
\hline Mengangkut material dari WIP Rit ke mesin Rit & 9 \\
\hline Mengangkut material dari mesin Rit ke WIP potong keping & 6 \\
\hline Mengangkut material dari WIP potong keping ke mesin potong keping & 35.5 \\
\hline Mengangkut material dari mesin potong keping ke WIP sortir & 26 \\
\hline Mengangkut material dari WIP sortir ke area sortir & 26.5 \\
\hline Mengangkut material dari area sortir ke WIP QC sampling & 12 \\
\hline Mengangkut material dari WIP QC sampling ke area packing & 11 \\
\hline Mengangkut material dari area packing ke area wrapping & 20 \\
\hline Mengangkut dari area wrapping ke staging area & 15 \\
\hline \multicolumn{2}{c}{ Total } \\
\hline
\end{tabular}

\section{Penyebab Excess Processing waste}

Hasil pnelitian menunjukkan bahwa pada proses produksi etiket "H", beberapa penyebab aktivitas yang menimbulkan excess processing antara lain adalah proses atau aktivitas identifikasi bahan baku oleh Quality Assurance (QA) dan proses penempelan label QA pass pada bahan baku. Dalam aktivitasnya, proses ini menunjukkan tidak adanya stándar pengerjaan sehingga timbul variasi aktivitas yang tinggi yang pada akhirnya menyebabkan excess processing yang tinggi.

\section{E. Penyebab Inventories waste}

Terjadinya waste inventories disebabkan karena tidak adanya kebijakan persediaan pengaman (safety stock) dari perusahaan sehingga produk yang disimpan di warehouse (baik warehouse bahan baku maupun warehouse produk jadi) tidak tetap antar waktunya. Tidak adanya kebijakan safety stock yang diterapkan perusahaan yang berubah-ubah akan mengakibatkan variansi dalam inventory, dimana inventory akan sangat tinggi jika permintaan rendah dan sebaliknya, inventory akan sangat rendah saat ada permintaan (demand) yang tinggi.

\section{F. Penyebab Motion waste}

Pada proses produksi etiket "H" terjadi motion pada beberapa aktivitas antara lain: Pengambilan peralatan dan spareparts di tool room, dan mencari hand pallet untuk mengangkut material. serta Mengangkat kertas ke mesin potong (blangko dan keping). Hasil pengamatan analisa postur kerja menunjukkan bahwa nilai LI sebesar 2,854 pada kondisi origin dan 2,950 pada kondisi destination. Karena nilai $\mathrm{LI} \geq 1$, pekerjaan dapat menyebabkan resiko cedera tulang belakang karena berat beban melebihi batas pengangkatan.

\section{G. Penyebab Defects}

Produk defect (cacat) seringkali dihasilkan dalam proses produksi etiket " $\mathrm{H}$ ". Defect muncul karena terjadi downtime pada mesin. Ada beberapa penyebab terjadinya downtime mesin yaitu dari segi manusia, mesin, material dan metode. Berikut ini adalah diagram sebab akibat terjadinya downtime pada mesin. 


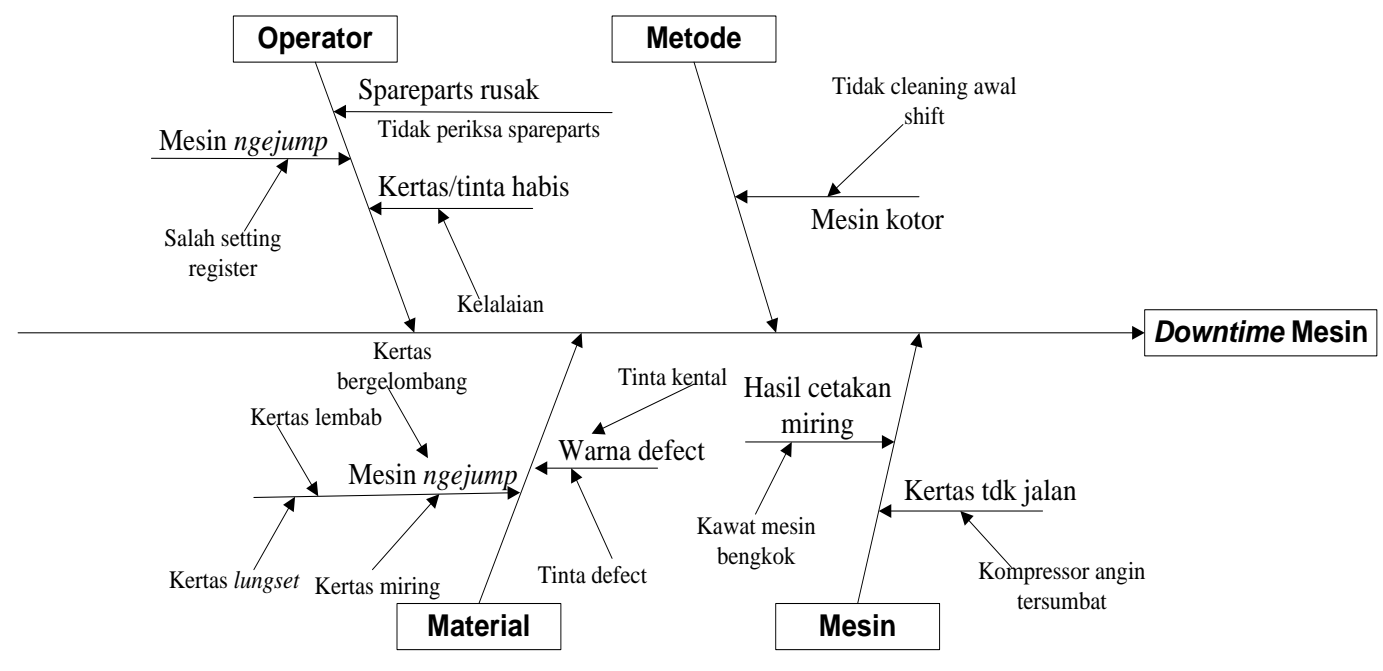

Gambar 4 Diagram sebab akibat downtime mesin.

\section{H. Rekomendasi Perbaikan}

Proses rekomendasi perbaikan dibuat berdasarkan hasil analisa penyebab waste yang terjadi dan kondisi serta batasan-batasan yang dimiliki perusahaan saat ini. Untuk perbaikan Overproduction, perencanaan produksi dibuat berdasarkan target produksi untuk setiap bulannya (schedule production monthly) yang ditetapkan oleh pihak PPC. Secara teknis setiap minggu pihak produksi membuat kartu produksi yang berisi nomer job/order produksi, alokasi waktu penyelesaian, target produksi dan realisasi produksi untuk setiap proses produksi yang mengacu pada schedule production monthly yang ditetapkan oleh pihak PPC. Penilaian kinerja operator tidak hanya berdasarkan pencapaian uptime yang tinggi, tetapi juga menilai kesesuaian antara target produksi dengan realisasi produksi. Secara teknis, setiap bulan dilakukan penilaian kinerja untuk masing-masing operator terkait dengan pencapaian uptime dan kesesuaian target produksi.

Overproduction dapat memberikan kerugian bagi perusahaan antara lain: menimbulkan biaya simpan, biaya produksi dan biaya tenaga kerja yang sebenarnya tidak perlu terjadi. Melaksanakan briefing tiap awal shift untuk mengingatkan taget produksi pada saat itu. Menempelkan update target dan realisasi produksi tiap hari pada mading di area produksi.

Tabel 4 Kartu produksi mingguan.

\begin{tabular}{|c|c|c|}
\hline $\begin{array}{l}\text { Kar } \\
\text { No. Job/Orde } \\
\text { Merek Produ } \\
\text { Tanggal Prod }\end{array}$ & $\begin{array}{l}\text { Produksi Mi } \\
\text { o01EH120S0110 } \\
\text { Etiket "H" } \\
=7 \text { Januari-14 Jar }\end{array}$ & uan \\
\hline Proses & Target Produksi & $\begin{array}{l}\text { Realisasi } \\
\text { Produksi }\end{array}$ \\
\hline $\begin{array}{l}\text { Potong Blangkc } \\
\text { Cetak } \\
\text { Rit } \\
\text { Potong Keping } \\
\text { Sortir }\end{array}$ & & \\
\hline
\end{tabular}

Melaksanakan rapat rutin setiap bulan untuk membahas masalah yang terjadi terkait overproduction dengan semua pihak yang terkait dan membuat pamflet dan poster pada area produksi terkait dengan pentingnya menghindari terjadinya overproduction. 
Untuk usulan perbaikan untuk mengatasi masalah pada proses yang mengalami waiting antara lain:

1. Pihak warehouse masih membuat bukti penerimaan barang sehingga bahan baku belum bisa diturunkan dari truk. Hal ini terjadi karena pihak warehouse tidak mengetahui kedatangan bahan baku sehingga pembuatan bukti penerimaan barang dilakukan saat bahan baku datang.

2. Tidak tersedianya forklift dapat diatasi dengan membuat penjadwalan pemakaian forklift antara warehouse bahan baku dengan warehouse produk jadi. Akan tetapi apabila pemakaian forklift disaat yang sama, maka dapat digunakan hand pallet sebagai alternatif material handling.

3. Pihak QA menungu dikirimkannya receiving report (RR) dari warehouse. Untuk itu diberikan usulan perbaikan yaitu pembuatan receiving report (RR) dilakukan oleh supplier dan dikirim sebelum kedatangan bahan baku.

4. Pihak QA meminta jadwal kedatangan bahan baku dari supplier agar dapat mempersiapkan inspeksi secara lebih awal. Selain itu pihak QA juga harus sering menghubungi pihak warehouse terkait dengan kedatangan bahan baku.

5. Pihak QA meminta supplier mengirimkan lab sampel dari bahan baku yang akan dikirim. Pengiriman lab sampel ini dilakukan sebelum kedatangan bahan baku. Dengan demikian pengambilan sampel secara langsung di warehouse tidak perlu dilakukan lagi.

Sedangkan untuk perbaikan transportation waste, proses pengiriman produk jadi dilakukan dari warehouse produk jadi tanpa melalui long term storage (LTS) langsung menuju konsumen. Adanya satu mesin potong yang digunakan khusus untuk proses potong keping. Mesin ini diletakkan terpisah dengan mesin potong yang khusus untuk proses potong blangko. Menghilangkan area sortir dan WIP sortir (tidak melalui proses sortir). Menyatukan area sampling QA dengan area packing pada satu area yang sama. Gambar berikut memperlihatkan diagram aliran produksi etiket " $H$ " setelah dilakukan perubahan layout.

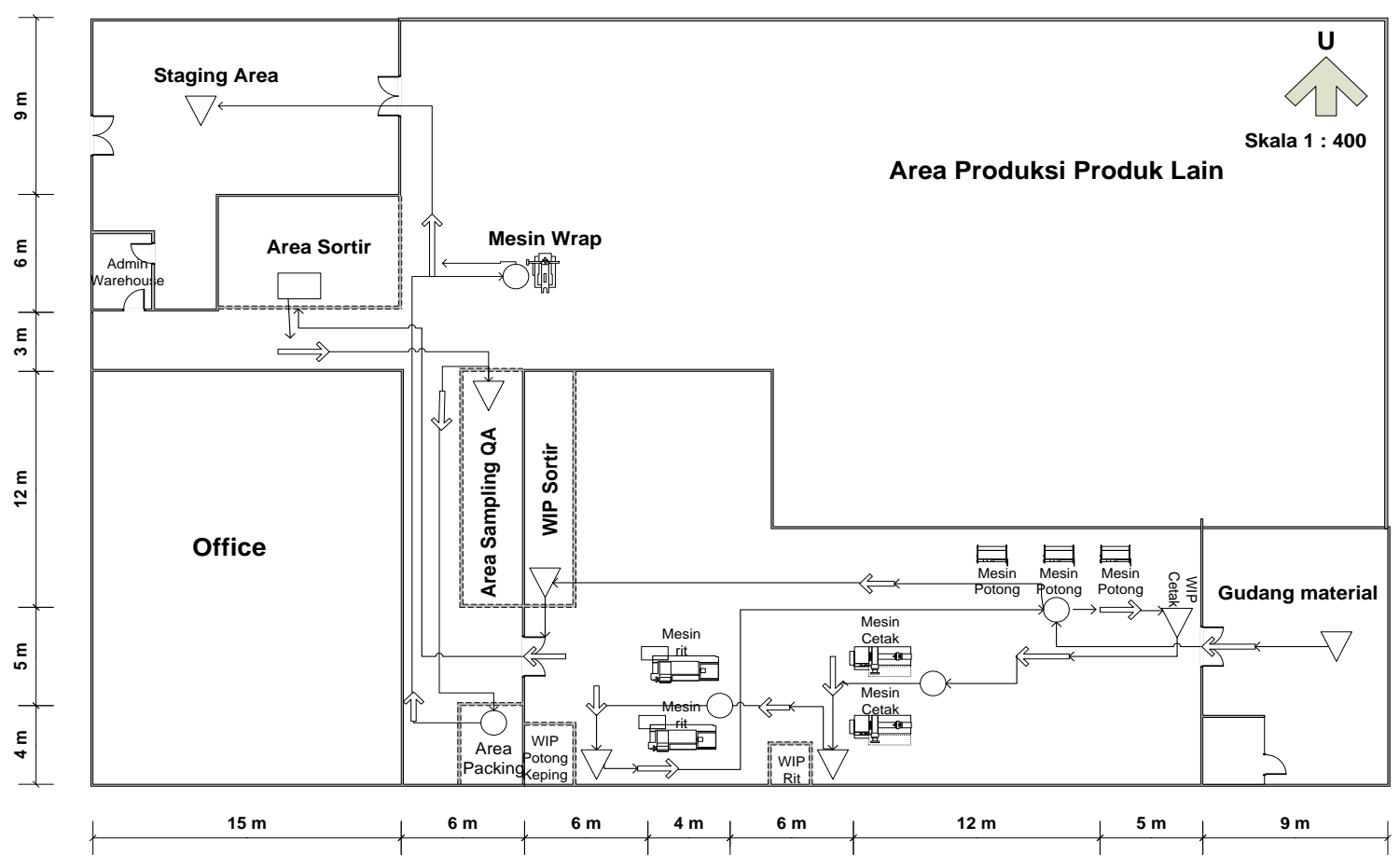

Gambar 5 Diagram aliran proses produksi etiket "H" (usulan). 
Dari gambar diatas dapat dihitung jarak perpindahan aliran proses dalam 1 siklus proses sebagai berikut.

Tabel 5 Jarak Perpindahan (usulan)

\begin{tabular}{ll}
\hline Aktivitas & Jarak (m) \\
\hline Mengangkut material dari area produksi ke mesin potong blangko & 14 \\
\hline Mengangkut material dari mesin potong blangko ke WIP cetak & 4 \\
\hline Mengangkut material dari WIP cetak ke mesin cetak & 13.5 \\
\hline Mengangkut material dari mesin cetak ke WIP Rit & 9 \\
\hline Mengangkut material dari WIP Rit ke mesin Rit & 9 \\
\hline Mengangkut material dari mesin Rit ke WIP potong keping & 6 \\
\hline Mengangkut material dari WIP potong keping ke mesin potong keping & 32.5 \\
\hline Mengangkut material dari area potong keping ke WIP QC sampling & 36.5 \\
\hline Mengangkut material dari WIP QC sampling ke area packing & 0 \\
\hline Mengangkut material dari area packing ke area wrapping & 9 \\
\hline Mengangkut dari area wrapping ke staging area & 15 \\
\hline Total & $\mathbf{1 4 8 . 5}$ \\
\hline
\end{tabular}

Sementara itu, untuk usulan perbaikan dari terjadinya Excess processing dapat dilakukan dengan melakukan perbaikan perubahan urutan proses produksi seperti gambar 6.

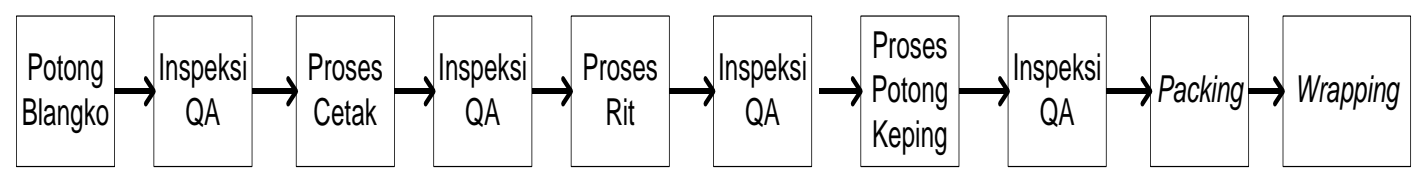

Gambar 6 Urutan proses produksi etiket "H" (usulan).

Usulan urutan prosess ini dibuat agar tidak ada lagi aktivitas-aktivitas proses yang akan mengakibatkan excess processing seperti pada identifikasi bahan baku oleh Quality Assurance (QA) dan proses penempelan label QA pass pada bahan baku pada kondisi awal.

Sedangkan untuk masalah lamanya inventories yang terjadi di warehouse dapat diatasi dengan menggunakan kebijakan safety stock. Berikut ini adalah perhitungan safety stock dari produk jadi etiket " $\mathrm{H}$ ".

$$
\begin{aligned}
\text { SS } & =\text { z.s. } \sqrt{t} \\
& =2,06 \times 2,67 \times \sqrt{2} \\
& =7,76 \text { pallet } \approx 8 \text { pallet }
\end{aligned}
$$

Average stock level $(\mathrm{ASL})=$ Rata-rata permintaan selama lead time + SS

$$
\begin{aligned}
& =46,28+8 \\
& =54,28 \text { pallet } \approx 54 \text { pallet }
\end{aligned}
$$

Average inventory level $(\mathrm{AIL})=\frac{A S L}{\text { Rata }- \text { rataPermin taan }}$

$$
\begin{aligned}
& =\frac{54}{23,14} \\
& =2,33 \text { minggu } \approx 2 \text { minggu }
\end{aligned}
$$

Dengan demikian pengiriman produk jadi akan bersifat FIFO (first in first out).

Usulan perbaikan motion waste dengan dilakukan dengan menerapkan pengambilan peralatan dan spareparts di tool room, Pemakaian toolbox yang disimpan didekat area mesin akan memudahkan apabila operator membutuhkan peralatan. Mencari hand pallet untuk mengangkut material.penyimpanan hand pallet agar tidak 
kesulitan lagi saat akan menggunakannya. Setiap orang yang telah menggunakan hand pallet.

Sedangkan usulan untuk mengurangi defect dapat dilakukan dengan mengurangi Downtime mesin sebagai penyebab terjadinya defect dengan melakukan suatu perbaikan. Berdasarkan hasil identifikasi penyebab terjadinya downtime mesin dengan menggunakan diagram sebab akibat, dapat dilakukan perbaikan. Berikut ini adalah usulan perbaikan terkait dengan masalah downtime mesin yang dilihat dari aspek manusia, metode kerja, material dan mesin.

\section{KESIMPULAN}

Terdapat beberapa pemborosan (wastes) yang terjadi dalam proses produksi "etiket $\mathrm{H}$ " sepanjang value stream seperti overproduction, waiting, transportation, excess processing, inventories, motion, dan defect. Berdasarkan analisis yang dilakukan diketahui bahwa penyebab uatam terjadinya waste adalah Overproduction, waiting, Transportation, Excess processing, Inventories, Motion, Defect.

Beberapa rekomendasi perbaikan telah diusulkan untuk meminimasi pemborosan (waste) tersebut. Misalnya untuk Overproduction, diatasi dengan pembuatan kartu produksi untuk mengontrol jumlah produksi dan melakukan briefing tiap awal shift. Untuk Waiting time diatasi dengan pengaturan penggunaan forklift, penyiapan administrasi sebelum kedatangan atau pengiriman produk, adanya receiving report (RR) dan lab sampel dari supplier. Sedangkan untuk transportation sebaiknya dilakukan pengaturan tata letak fasilitas dalam proses produksi, sementara itu Excess processing sebaiknya dilakukan penggunaan barcode number, memperketat inspeksi produk yang dilakukan oleh operator dan QA teknisi. Untuk waste Inventories diatasi dengan pengaturan area penyimpanan produk berdasarkan waktu kedatangan agar dapat bersifat FIFO (first in first out) dan adanya kebijakan safety stock untuk persediaan di warehouse. Sedangkan untuk waste Motion sebaiknya dilakukan penggunaan alat bantu berupa toolbox dan lifter pengangkat serta adanya area khusus untuk penyimpanan hand pallet dan akhirnya untuk waste Defect perlu dilakukan preventive maintenance, memperketat inspeksi bahan baku sebelum dimasukkan ke mesin, dan adanya standarisasi setting register.

\section{DAFTAR PUSTAKA}

[1] Gasperz, V., \& Fontana, A. Lean Six Sigma for Manufacturing and Engineering (p. 6). Kuala Lumpur: International Conference on

[2] Industrial Engineering and Operations Management, (2011). [3] Sabta Adi, Kusuma. Penerapan Lean Manufacturing Dalam Mengidentifikasi Dan Meminimasi Waste Di PT. Hilton Surabaya.

[3] Undergraduate Thesis. UPN Jatim: Surabaya, (2010). [4] Singgih, M. L., \& Tjiong, W. Perbaikan Sistem Produksi Divisi Injection Dan Blow Plastik. Prosiding Seminar Nasional Manajemen

[4] Teknologi Xiii, 8. Doi:978-602-97491-2-0, (2011). [5] Melton, T. The Benefits Of Lean Manufacturing. Chemical Engineering

[5] Research And Design, 83(6), 662-673. Doi:10.1205/Cherd.04351, (2005). [6] Anvari A, I. Y., Hojjati S M H 2011. A Study On Total Quality

[6] Management And Lean Manufacturing: Through Lean Thinking

[7] Approach. World Applied Sciences Journal, 12 (9), 11.[7] Hines, P., \& Taylor, D. Going Lean. Lean Entreprise Research Centre.

[8] Cardiff Business School. UK, (2000). [8] Anityasari, M., \& Wessiani, NA. Analisa Kelayakan Usaha Dilengkapi dengan Kajian Manajemen Resiko. Surabaya: Guna Widya, (2011). 